\title{
BIOTECHNOLOGY MODULE BASED ON SOCIOSAINTIFIC ISSUES TO IMPROVE STUDENT'S CRITICAL THINKING ABILITY THROUGH ONLINE LEARNING
}

\author{
Nia Alfitriyani ${ }^{1}$, Indarini Dwi Pursitasari2 ${ }^{2}$, Surti Kurniasih ${ }^{2}$ \\ ${ }^{1}$ MTs Negeri 6 Majalengka \\ ${ }^{2}$ Program Studi Pendidikan IPA Sekolah Pascasarjana Universitas Pakuan \\ *Email: indarini.dp@unpak.ac.id
}

DOI: $10.26418 /$ jpmipa.v12i1.43179

\begin{abstract}
This research aims to develop a science learning module based on Socio Scientific Issues on biotechnology materials that can improve students' critical thinking skills. This research is an $R \& D$ research with a 4-D design. Validation is carried out by science experts and teachers. The module readability test and the students' responses to the module were obtained using a close test and questionnaire. Data analysis was performed descriptively quantitatively. The results of the module validation by expert lecturers obtained $89 \%$ and an average CVI value of 0.98 with a very valid category and was suitable for use. The module readability test results were $42.22 \%$ with the instructional level category indicating that the modules needed to be learned. The results of the $N$-Gain test for critical thinking ability is 0.59 , the module is in the moderate category and the students' response value to the module by $87.50 \%$ showed the response in the very good category to the use of module-based SSI in learning to improve critical thinking skill.
\end{abstract}

Keywords: Socioscientific issues; Biotechnology; Critical Thinking Skill.

\section{INTRODUCTION}

The 21 st century is marked as the century of globalization Boholano (2017), which means that human life in the 21 st century undergoes rapid changes that encourage competitiveness (Van, et al., 2017) and is different from the system of life in the previous century. The changes that occur not only have an impact on the global economy, national education has also undergone enormous changes (Bell, 2016; Hussin, 2018). One of the major impacts in education is the development of 21st-century skills (Henriksen, et al., 2016; Siddiq, et al., 2016; Egan, et al., 2017). The 21stcentury skills described by the US-based Partnership for 21st Century Skills (P21) identify the competencies needed in the 
21st century, namely "The 4Cs" communication, collaboration, critical thinking, and creativity (Chu, et al., 2017; Whorton, et al., 2017; Eryandi \& Nuryanto, 2020; Frache, et al., 2019; Spies \& Xu, 2018).

These competencies are important to be taught to students in the context of core subject areas and 21st-century themes (Qian \& Clark, 2016). The demands of 21 st-century skills must collaborate with the curriculum used (Zulkarnaen, et al., 2019) as a basis for developing learning tools to create learning that is following the needs of society and the times.

One of the supporting tools for learning is a module. Modules are books that consist of several topics and are arranged based on learning designs, and are distributed to students for use in learning activities (Kemenristekdikti, 2017). Module development must be accompanied by using a specific learning approach or model to improve the targeted skills (Yulastri \& Hidayat, 2017; Khabibah, et al., 2017; Pratono, et al., 2018; Irwan, et al., 2019). In 21stcentury learning, many approaches and models are suitable for use in the development of soft skills of students, including the socio-scientific issue approach (Hancock, et al., 2019). The results showed that a lesson that uses a sociocultural issue approach can improve 21 st-century skills, such as critical thinking skills. Pratiwi, et al. (2016); Cahyarini, et al. (2016); Lathifah \& Susilo (2016); Santika, et al. (2018), scientific literacy Rubini, et al. (2019); Widiyawati (2020), decision making Dauer \& Forbes (2016); Nurtamara (2020), communication skills Chung, et al. (2016), Purwati's argumentation skills (2019), and problem-solving skills (Zamakhsyari \& Rahayu, 2020). Therefore, modules based on socioscientific issues need to be developed to support 21st-century learning to train and develop student soft skills.

Based on data on the distribution of questionnaires conducted on science teachers in West Java regarding the use of teaching materials, only $18.5 \%$ of teachers used modules in learning. Most teachers still use textbooks provided by the government to support learning. The preliminary test results in one of the junior high schools in Majalengka showed the average critical thinking ability of students was $36.67 \%$. The results of interviews with science teachers at the school stated that some of the factors causing the students' low critical thinking skills were inadequate learning facilities, varied student characteristics, lack of student motivation, and the lack of teaching materials and innovative application of learning.

One of the innovative learning is learning that is associated with linking socio-scientific issues (Sadler, et al., 2016) to encourage students to use reasoning, problem-solving, critical thinking skills, and creative thinking skills (Setambah, 2018; Zamakhsyari \& Rahayu, 2020; Saad, et al., 2017). Socioscientific issues are topics or issues that live socially, have a scientific component, and intersect with other disciplines such as politics, economics, and ethics (Ismawati \& Wicaksono, 2019; Herman, et al., 2018). Socioscientific issues can be used as a means to explain social problems that 
occur in the scientific field (Rahman, 2018; Hancock, et al., 2019; Karisan \& Zeidler, 2017; Lindahl, et al., 2019; Owens, et al., 2017). Socio-scientific issues make science learning relevant to student life (Pitpiorntapin \& Topcu, 2016; Zeidler, et al., 2019; Sadler, et al., 2017). Besides, innovative learning that integrates socio-scientific issues can improve skills needed in the 21 st century (Sismawarni, et al., 2020; Mahanani, et al., 2019; Nazilah, et al., 2019; Yacoubian \& Khishfe, 2018; Evren, 2018; Chowdhury, et al., 2019).

Many scientific materials can be applied using sociocultural issues, including acid-base material Kusumaningtyas, et al. (2020); materials of electrolyte and non-electrolyte solutions Rudibyani, et al. (2019); global warming Ozden (2017); climate change Eggert, et al. (2017); learning biology Suwono, et al. (2017); Owens, et al. (2019); Tidemand \& Nielsen (2017); biotechnology material (Khishfe, et al., 2017; Peel, et al., 2019). The use of social scientific issues is suitable for application in biotechnology learning (Wan \& Bi, 2020). The problems arising from biotechnology are closely related to the daily lives of students (Suratno, et al., 2018). Learning sources that come from contextual problems can train students' critical thinking skills (Sofiatin, et al., 2016).

For learning to take place well, it needs to be equipped with teaching materials in the form of modules. The existence of modules is very much needed by students during the Covid-19 pandemic, which demands student learning independence (Susanti \& Djukri, 2018; Yusro \& Sasono, 2016).
Student learning independence can improve academic achievement or learning outcomes, thinking patterns, and critical thinking skills. Arifin, et al. (2016); Egok (2017), Fajriyah's reasoning ability, et al. (2019), Sundayana's problem-solving ability (2016), and is closely related to students' attitudes and self-confidence (Pratiwi \& Laksmiwati, 2016). Therefore, it is necessary to develop a biotechnology module based on socio-scientific issues as a teaching material used during the Covid-19 pandemic to train and improve students' critical thinking skills.

\section{METHODS}

The research method used is research development or Research and Development (R\&D). The research design carried out refers to the 4-D development model from Thiagarajan, Semmel, and Semmel (Hendripides \& Hikmah, 2018). The 4-D development model consists of the stages of define, design, develop, and design. However, this research only reached the development stage.

Activities at the define stage are carried out to define and define development requirements. In other models, this stage is often called a needs analysis. Five activities are carried out at the defined stage, namely preliminary analysis, student analysis, task analysis, concept analysis, and formulation of learning objectives. The next stage is a design that aims to design a biotechnology module based on aspects of socio-scientific issues and research instruments. The research instrument was designed as an expert assessment form, a gap test, a critical thinking ability 
test, a student response questionnaire. Furthermore, at the development stage, three experts conducted module validation and research instruments. The three expert validators provide ratings and suggestions for improvement. After the module was revised, 20 science teachers were assessed to determine the Content Validity Ratio (CVR) and Content Validity Index (CVI), as well as a readability test by 35 students. The revised socio-scientific issue-based module was then tested on 28 class IX students of MTsN 6 Majalengka in online biotechnology learning. Limited trials were carried out with the weak experiment method and the one-group pretest-posttest design (Rahi, 2017). Students' critical thinking skills are determined using a valid critical thinking ability test. The critical thinking ability test was tested at the end of the lesson. Besides, questionnaires were also distributed to determine student responses. The data on students' critical thinking skills were calculated $\mathrm{N}$-gain and tested inferential statistically. The student response data were processed and analyzed descriptively quantitatively.

\section{RESULTS AND DISCUSSION}

The Covid-19 pandemic has changed the order of life in all fields. Learning has also undergone a change from face-to-face learning in a classroom or laboratory to learning that is carried out online. Online learning requires teachers to be more creative and innovative in designing learning activities and teaching materials in the form of modules. The development of a module based on socioscientific issues has been carried out with details of the development stages as follows:

\section{Curriculum Analysis}

The results of the curriculum analysis and the macro and micro proportions show that some science subject materials can be packaged by presenting socio-scientific issues. One of the materials most often presented in the context of sociocultural issues is "Biotechnology". Many issues can be explored in society related to biotechnology, such as problems in the environment, ethics of scientists in research, use of biotechnology products, and so on (Pope, et al., 2017; Tidemand \& Nielsen, 2017; Hancock, et al., 2019). Issues in society about this biotechnology material can be used as a learning resource. Several studies that use sociocultural issues in science learning have been conducted by Arifin, et al. (2016), Egok (2017), Fajriyah, et al. (2019), Sundayana (2016), and Pratiwi \& Laksmiwati (2016) to improve academic achievement, learning outcomes, thinking patterns and critical thinking skills, reasoning skills, problem-solving abilities, improving student attitudes and self-confidence.

\section{Design Stage}

The SSI module with the theme Biotechnology is developed based on socio-scientific characteristics which are combined into biotechnology materials. Biotechnology material is included in the module based on curriculum analysis and the proportion of macro and micro biotechnology materials. Based on the analysis results, 4 sub-concepts will be used as subtitles in the module. The four sub-concepts are the definition and history 
of biotechnology; conventional biotechnology and modern biotechnology; application of biotechnology in various fields; and the impact of the application of biotechnology in human life. Socio-scientific aspects consist of 7 aspects, namely 1) the problems faced are real, not artificial, 2) contemporary relevance, 3) controversial, 4) describe the nature and process of science, 5) problems are complex and open, 6) combine science, technology, and social issues, and 7) considering the ethical dimensions (Rahman, 2018; Sadler, et al., 2017; Sadler, et al., 2016; Tidemand \& Nielsen, 2017; Herman, et al., 2018; Bayram, et al., 2019)

These sociocultural aspects are contained in the module in the form of global issues made in the column of biotechnology issues equipped with a column of questions to train students' critical thinking skills. The column on biotechnology issues is a characteristic that is quite prominent in this module as shown in Figure 1.
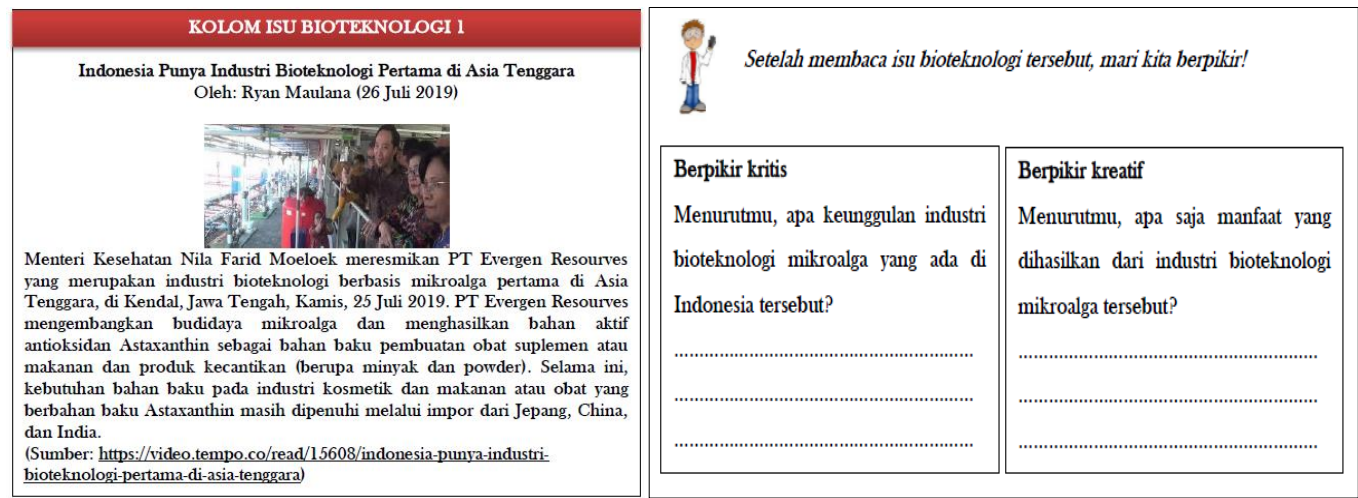

Figure 1. Characteristics of SSI-Based Biotechnology Modules

All aspects of socio-scientific issues are integrated into modules in the form of biotechnology issues. Biotechnology issues are presented following biotechnology topics. Each sub-chapter title presents biotechnology issues with different themes. Indicators of socio-scientific issues can be used to train students' thinking skills. According to Hancock, et al. (2019) stated that the use of socioscientific issues as a context for school education is important because education must address interdisciplinary learning and holistic learning rather than subject-based learning. Value-based learning and learning to think critically are better developed than learning that requires students to memorize and is participatory. The ability to think critically is also important for students to solve problems, critical thinking is seen as a prerequisite for the growth of problem-solving abilities Cahyono (2017) and making correct decisions (Nuryanti, et al., 2018).

\section{Develop Stage}

Module validation is carried out by lecturers and science practitioners/teachers. The assessment 
component consists of aspects of content feasibility, presentation feasibility, components of socioscientific issues, graphics, and language feasibility. The results of the validation by expert lecturers can be seen in Table 1.

Table 1. Expert Validation Results by Expert Lecturers

\begin{tabular}{lcccc}
\hline \multirow{2}{*}{ Component } & \multicolumn{3}{c}{ Validator's average value } & \multirow{2}{*}{ Average } \\
& VAL-1 & VAL-2 & VAL-3 & \\
\hline Content Eligibility & 4.5 & 4 & 4.3 & 4.3 \\
Serving Eligibility & 4.8 & 5 & 4.3 & 4.7 \\
Socio-scientific issues & 4.6 & 5 & 4.3 & 4.6 \\
Graphics & 4.3 & 5 & 4 & 4.4 \\
Language Eligibility & 4 & 5 & 4 & 4.3 \\
\hline Average and Criteria = 4.46 (89.2\%): The quality of the modules in \\
the category is very good \\
\hline
\end{tabular}

Table 1 shows the highest assessment on the presentation feasibility component with an average of 4.7. This is because the presentation of the module is equipped with content that attracts students 'attention such as columns on biotechnology issues that can add to students' insight. The acquisition of high presentation aspect values is expected to increase student interest and motivation. In line with the results of Budiarso (2016) and Lestari (2016) that teaching materials developed with a fun model can increase student motivation. In another study, Pursitasari, et al. (2019) states that teaching materials with fun content can increase student interest in learning, thereby increasing students' scientific literacy skills. Meanwhile, the module component that received the lowest average rating was content feasibility. Some of the things that cause the low value of the content feasibility are the lack of spiritual value in the module. Overall, the results of the module assessment by the experts scored $89.2 \%$ in the very good category. Some input from experts is correcting inaccurate and non-standard words, changing colors that do not match in the module layout, and changing some module layouts so that no space appears empty in the module sheet. Module improvements are carried out based on suggestions provided by experts. These suggestions include replacing inaccurate words, such as changing "Preface" to "Foreword", "Concept Map" to "Concept Chart". Improvements were also made in terms of module appearance, such as changing the colors to match them.

In addition to the results of expert assessments, the module also received an assessment from the teacher to determine CVR and CVI with the results shown in Table 2 . Almost all of the components of the assessment obtained a CVR of 1.0, except for the socio-scientific issue component with an average of 0.96 . Table 2 also shows the CVI value of 0.98 . These results indicate that the modules developed in terms of

Nia Alfitriyani, Indarini Dwi Pursitasari \& Surti Kurniasih

Biotechnology Module Based on Sociosaintific Issues to Improve Student's Critical Thinking Ability Through Online Learning 
content, presentation, components of socio-scientific, graphic, and language issues are appropriate and suitable for use in learning. The determination of CVR and CVI values in module development is carried out to determine the feasibility of a module for use in the learning process. The determination of CVR and CVI has also been carried out by practitioners (science teachers) with CVI results of 0.98 in the very good, valid, and feasible category for use in learning.

Table 2. Results of Expert Validation by Practitioners (Science Teachers)

\begin{tabular}{lc}
\multicolumn{1}{c}{ Component } & Average CVR \\
\hline Content Eligibility & 1 \\
Serving Eligibility & 1 \\
Socio-scientific & 0.96 \\
issues & \\
Graphics & 1 \\
Language & 1 \\
Eligibility & \\
\hline CVI value & 0.98 \\
Category & Very Good \& Valid \\
\hline
\end{tabular}

Before the module is used in learning, the readability test is carried out to determine the level of ease with which the module is used by students. The legibility test results are shown in Figure 2.

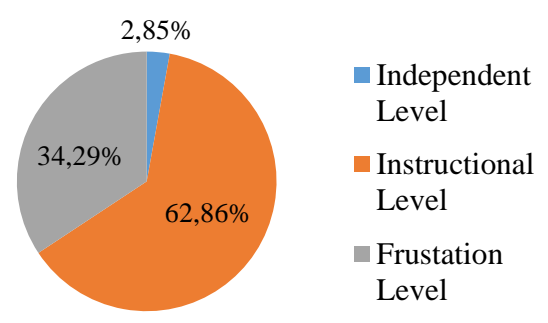

Figure 2. Readability Test Results for SSI-Based Biotechnology Module
Figure 2 shows the distribution of readability test values of $2.85 \%$ at the independent level, $62.86 \%$ at the instructional level, and $34.29 \%$ at the frustration level. The average readability test result was $42.22 \%$ with the instructional level category. This shows that the module can be used in learning with teacher guidance. The readability test of teaching materials has also been carried out by Kartika, et al. (2019). The results of the research show the readability of the module with a value of $55.89 \%$ in the instructional category, which means that students need guidance from the teacher to use teaching materials in the learning process.

\section{Student Thinking Skills}

Based on the legibility test results, the SSI-based biotechnology module being developed is included in the instructional category. Therefore, this module is implemented in Biotechnology learning. Learning using SSI-based modules is carried out online because of the Covid-19 Pandemic. Online learning is carried out using zoom media through a scientific approach. Before and after Biotechnology learning activities using a module based on socioscientific issues, pre-test and post-test were carried out to determine the increase in participants' high critical thinking skills.

Learning begins by providing pre-test sheets to students via a google form. Then, learning is carried out using the zoom application for discussion of the material being

Nia Alfitriyani, Indarini Dwi Pursitasari \& Surti Kurniasih

Biotechnology Module Based on Sociosaintific Issues to Improve Student's Critical Thinking Ability Through Online Learning 
studied. After the discussion process is complete, students are given assignments according to the instructions in the module. One of the tasks is a project to make yogurt and make video documentation. Learning discussions through zoom was held 3 times with different material discussions. After the learning process through zoom is complete, students do a posttest via a google form.

The results of the pretest and post-test of students 'critical thinking abilities were then analyzed to determine the $\mathrm{N}$ gain of students' critical thinking abilities. The N-Gain value of 0.59 indicates that the use of the SSI-based biotechnology module is in the moderate category or is effective enough to improve students' critical thinking skills. $92.86 \%$ of students had an average $\mathrm{N}$-Gain score in the medium category and $7.14 \%$ of students had an average N-Gain score with the high category. The increase in critical thinking skills is still in the moderate category after students take Biotechnology learning using sociocultural issue-based modules because online learning has several obstacles such as the inequality of students having devices, limited internet quotas, and ineffective discussion processes. This is reinforced by the findings of other studies which state that the obstacles to online learning are unstable internet networks, inadequate internet quotas, lack of parental supervision, and more difficult learning management (Jariyah \& Tyastirin, 2020; Rigianti, 2020).

The ability to think critically of students when viewed on each student's critical thinking indicator such as reason, inference, situation, clarity, and overview shows that the NGain value of the indicator of the highest critical thinking ability is an overview of 0.92 . This is because the socio-scientific issue-based module contains question exercises that require students to double-check the answers they give. In the module, there is also an answer key, so that students can independently correct the answers they have given. This can develop students' accuracy in doing each exercise given. Based on the research results of Ulfa, et al. (2018) familiarize students with re-checking the answers given as a whole can train students' accuracy so that students can to find alternative answers to solve problems, this is called overview ability. The lowest $\mathrm{N}$-gain is on the reason indicator of 0.54 . The cause of the low reason indicator is because the module still does not provide a means for students to provide reasons for each answer given.

\section{Student Responses to SSI Based Modules}

After the science lesson using the SSI-based biotechnology module was carried out, students gave positive responses. This is shown in Table 3. 
Table 3. Student Responses to SSI Based Biotechnology Modules

\begin{tabular}{clc}
\hline No. & \multicolumn{1}{c}{ Statement } & $\begin{array}{c}\text { Percentage of } \\
\text { Positive Student } \\
\text { Feedback (\%) }\end{array}$ \\
\hline 1 & Understand the language used in the module & 78.6 \\
2 & Enjoy learning using modules & 100 \\
3 & Modules are useful in science learning & 100 \\
4 & Modules help in understanding the concept of Biotechnology & 100 \\
5 & Have the high motivation to learn to use modules & 75 \\
6 & Learning is more effective by using modules & 96.4 \\
7 & Agreeing to further develop the module as a science learning & 92.9 \\
& medium in other materials & 75 \\
8 & Interested in the display module & 96.4 \\
9 & Interested in module design & 50 \\
10 & Module design supports understanding the concept of & 100 \\
& biotechnology & 85.7 \\
11 & Module design helps to broaden the horizons & 87.5 \\
\hline \multicolumn{2}{c}{ Module design motivates to learn more about the material } \\
\hline
\end{tabular}

Table 3 shows that the student response to the module of 87.5 was in the very good category and agreed to use the biotechnology module based on socio-scientific issues in learning. The highest scores on the questionnaire are found in statements $2,3,4$, and 11 regarding the use of modules in increasing understanding and increasing student insight. This is because the developed module contains a lot of the latest information about biotechnology, such as a column on biotechnology issues and a column of knowledge "Did you know?" to increase students' insight and knowledge. The lowest score on the questionnaire is in statement 10 regarding the module design which is less supportive of understanding the concept of biotechnology. The reason is that there are images that are not visible. This is an input and improvement for the module being developed.
The next lowest score is in the 5th and 8th statements with an average value of 75 . The fifth statement states students' motivation to use modules in learning. The reason is that students have started to feel bored with online learning during Covid-19 so that it has an impact on decreased learning motivation. As described by Alawamleh, et al. (2020), Usher, et al., (2020), and Patricia (2020) stated that student learning motivation decreased when learning online during Covid because students felt bored and preferred face-to-face learning. Then, the 8th statement expressed interest in the display module. The reason for the low value of the statement is because it is still related to statement 10 as a result of some pictures that are not visible.

\section{CONCLUSION}

The developed socio-scientific issuebased biotechnology module has valid

Nia Alfitriyani, Indarini Dwi Pursitasari \& Surti Kurniasih

Biotechnology Module Based on Sociosaintific Issues to Improve Student's Critical Thinking Ability Through Online Learning 
criteria based on expert judgment. The CVI acquisition also concluded that the module was feasible and could be used to study Biotechnology. The legibility test results show that the module being developed is at the instructional level so that in using the module, teacher assistance is needed in the learning process. The improvement

\section{REFERENCES}

Alawamleh, M., Al-Twait, L. M., \& AlSaht, G. R. (2020). The Effect Of Online Learning On Communication Between Instructors And Students During Covid-19 Pandemic. Asian Education and Development Studies.

Arifin, M., Dardiri, A., \& Handayani, A. N. (2016). Hubungan Kemampuan Penyesuaian Diri Dan Pola Berpikir Dengan Kemandirian Belajar Serta Dampaknya Pada Prestasi Akademik Mahasiswa. Jurnal Pendidikan: Teori, Penelitian, dan Pengembangan, 1(10).

Bayram-Jacobs, D., Henze, I., Evagorou, M., Shwartz, Y., Aschim, E. L., Alcaraz-Dominguez, S., ... \& Dagan, E. (2019). Science Teachers' Pedagogical Content Knowledge Development During Enactment Of Socioscientific Curriculum Materials. Journal of Research in Science Teaching, 56(9). of students' critical thinking skills is in the medium category, with indicators that have a high value is an overview and the lowest is the reason. In addition to an increase in critical thinking skills, students also gave a positive response to the use of sociological issue-based modules in studying Biotechnology material.

Bell, D. V. (2016). Twenty-first Century Education: Transformative Education For Sustainability And Responsible Citizenship. Journal of Teacher Education for Sustainability, 18(1), 48-56.

Boholano, H. (2017). Smart Social Networking: 21st Century Teaching And Learning Skills. Research in Pedagogy, 7(1), 21-29.

Budiarso, A. S. (2016). Pengembangan Bahan Ajar Berbasis Metode Hypnoteaching Untuk Memotivasi Siswa SMP Dalam Belajar IPA Pada Materi Energi Terbarukan. Jurnal Pena Sains, $3(2)$.

Cahyarini, A., Rahayu, S., \& Yahmin, Y. (2016). The Effect of 5e Learning Cycle Instructional Model Using Socioscientific Issues Learning Context on Students' Critical Thinking. Jurnal Pendidikan IPA Indonesia,5(2), 222-229. 
Cahyono, B. (2017). Analisis Ketrampilan Berfikir Kritis Dalam Memecahkan Masalah Ditinjau Perbedaan Gender. AKSIOMA: Jurnal Matematika dan Pendidikan Matematika, 8(1), 50-64.

Chowdhury, T. B. M., Holbrook, J., \& Rannikmäe, M. (2019). Teachers' Ownership Towards Using SocioScientific Issues for an Active Informed

Citizenry. EDULEARN19 Proc, 1, 3834-3840.

Chu, S. K. W., Reynolds, R. B., Tavares, N. J., Notari, M., \& Lee, C. W. Y. (2017). 21st Century Skills Development Through InquiryBased Learning. Singapore: Springer Singapore, 1007, 978981.

Chung, Y., Yoo, J., Kim, S. W., Lee, H., \& Zeidler, D. L. (2016). Enhancing Students'communication Skills In The Science Classroom Through Socioscientific

Issues. International Journal of Science and Mathematics Education, 14(1), 1-27.

Dauer, J. M., \& Forbes, C. (2016). Making Decisions About Complex Socioscientific Issues: A Multidisciplinary Science Course. Science Education \& Civic Engagement: An International Journal, 8(2), 5-12.

Egan, A., Maguire, R., Christophers, L., \& Rooney, B. (2017). Developing Creativity In Higher Education For 21st Century Learners: A Protocol For A Scoping
Review. International Journal of Educational Research, 82, 21-27.

Eggert, S., Nitsch, A., Boone, W. J., Nückles, M., \& Bögeholz, S. (2017). Supporting Students' Learning And Socioscientific Reasoning About Climate Change-The Effect Of ComputerBased Concept Mapping Scaffolds. Research in Science Education, 47(1), 137-159.

Egok, A. S. (2017). Kemampuan Berpikir Kritis Dan Kemandirian Belajar Dengan Hasil Belajar Matematika. Jurnal Pendidikan Dasar UNJ, 7(2), 186-199.

Eryandi, K. Y., \& Nuryanto, A. (2020). 21st Century Skills of Life Career Skills in Productive Learning of Vocational High School of Technical Expertise Engineering in Yogyakarta City. American Journal of Educational Research, 8(7), 480-484.

Evren-Yapıcıoğlu, A. (2018). Advantages And Disadvantages Of Socioscientific Issue-Based Instruction In Science Classrooms. International Online Journal of Education and Teaching (IOJET), 5(2), 361-374.

Fajriyah, L., Nugraha, Y., Akbar, P., \& Bernard, M. (2019). Pengaruh Kemandirian Belajar Siswa SMP Terhadap Kemampuan Penalaran Matematis. Journal on Education, 1(2), 288-296.

Frache, G., Tombras, G. S., Nistazakis, H. E., \& Thompson, N. (2019). Pedagogical Approaches To 21st 
Century Learning: A Model To Prepare Learners For 21 St Century Competencies And Skills In Engineering. In 2019 IEEE Global Engineering Education Conference (EDUCON), 711-717).

Hancock, T. S., Friedrichsen, P. J., Kinslow, A. T., \& Sadler, T. D. (2019). Selecting Socio-Scientific Issues For Teaching. Science \& Education, 28(6-7), 639-667.

Hendripides, S., \& Hikmah, N. (2018). Development of Innovative Teaching Materials Through Scientific Approach. Journal of Educational Sciences, 2(2), 14-22.

Henriksen, D., Mishra, P., \& Fisser, P. (2016). Infusing Creativity And Technology In 21st Century Education: A Systemic View For Change. Educational Technology \& Society, 19(3), 27-37.

Herman, B. C., Sadler, T. D., Zeidler, D. L., \& Newton, M. H. (2018). A Socioscientific Issues Approach To Environmental Education. Springer Nature, 3, 145-161.

Hussin, A. A. (2018). Education 4.0 Made Simple: Ideas For Teaching. International Journal of Education and Literacy Studies, 6(3), 92-98.

Irwan, I., Maridi, M., \& Dwiastuti, S. (2019). Developing Guided Inquiry-Based Ecosystem Module To Improve Students' Critical Thinking Skills. JPBI (Jurnal Pendidikan Biologi Indonesia), 5(1), 51-60.
Ismawati, R., \& Wicaksono, A. B. (2019). Pemanfaatan Isu Sosio-Saintifik Tradisi Menginang Sebagai Konteks Belajar Ipa Smp. Jurnal Pendidikan Sains (JPS), 7(2), 123128.

Jariyah, I. A., \& Tyastirin, E. (2020). Proses dan Kendala Pembelajaran Biologi di Masa Pandemi Covid19: Analisis Respon Mahasiswa. Jurnal Penelitian dan Pengkajian Ilmu Pendidikan: $e$ Saintika, 4(2), 183-196.

Karisan, D., \& Zeidler, D. L. (2017). Contextualization of Nature Of Science Within The Socioscientific Issues Framework: A Review Of Research. International Journal of Education in Mathematics, Science and Technology, 5(2), 139-152.

Kartika, I., Kurniasih, S., \& Pursitasari, I. D. (2019). Pengembangan Bahan Ajar Berbasis Socio-Scientific Issues Pada Materi Bioteknologi Untuk Meningkatkan Literasi Sains Siswa. Journal of Science Education and Practice. 3 (1), 112.

Kemenristekdikti. (2017). Panduan Penyusunan Perangkat Pembelajaran dan Bahan Ajar. Jakarta: Kemeristekdikti.

Khabibah, E. N., Masykuri, M., \& Maridi, M. (2017). The Effectiveness Of Module Based On Discovery Learning To Increase Generic Science Skills. Journal of Education and Learning, 11(2), 146-153.

Khishfe, R., Alshaya, F. S., BouJaoude, S., Mansour, N., \& Alrudiyan, K. I. 
(2017). Students' Understandings Of Nature Of Science And Their Arguments In The Context Of Four Socio-Scientific

Issues. International Journal of Science Education, 39(3), 299-334.

Kusumaningtyas, P., Oktafiani, R., Nurhadi, M., \& Sulistyaningwarni, S. (2020). Pengaruh Isu Sosiosaintifik Dalam Model Discovery Learning Terhadap Keterampilan Berpikir Kritis Siswa Pada Materi Asam Basa. Orbital:Jurnal Pendidikan Kimia, 64-74.

Lathifah, A. S., \& Susilo, H. (2016). Implementation of Socioscientific Issue Learning Through Symposium Method Based On Lesson Study to Improve Students' Critical Thinking in General Biological Course. Research Report.

Lestari, I. (2016). Pengembangan Bahan Ajar IPA Berbasis Komik Pada Pokok Bahasan Gerak Di SMP. Jurnal Pembelajaran Fisika, 4(5), 564-572.

Lindahl, M. G., Folkesson, A. M., \& Zeidler, D. L. (2019). Students' Recognition Of Educational Demands In The Context Of A Socioscientific Issues Curriculum. Journal of Research in Science Teaching, 56(9), 11551182.

Mahanani, I. Rahayu, S., \& Fajaroh, F. (2019). The Effect Of Inquiry Based Learning With Socioscientific Issues Context On Critical Thinking Skills And
Scientific Explanation. Jurnal Kependidikan. 3(1), 53-68.

Nazilah, N., Muharrami, L. K., Rosidi, I., \& Wulandari, A. Y. R. (2019). Pengaruh Bahan Ajar Berbasis Socio-Scientific Issues Pada Materi Pemanasan Global untuk Melatih Kemampuan Literasi Sains Siswa. Natural Science Education Research, 2(1), 8-16.

Nurtamara, L. (2020). The Effect of Biotechology Module with Problem Based Learning in the Socioscientific Context to Enhance Students' Socioscientific Decision Making Skills. International Education Studies, 13(1), 11-20.

Nuryanti, L., Zubaidah, S., \& Diantoro, M. (2018). Analisis kemampuan berpikir kritis siswa SMP. Jurnal Pendidikan: Teori, Penelitian, dan Pengembangan, 3(2), 155-158.

Owens, D. C., Sadler, T. D., \& Friedrichsen, P. (2019). Teaching Practices For Enactment Of SocioScientific Issues Instruction: An Instrumental Case Study Of An Experienced Biology Teacher. Research in Science Education, 1-24.

Owens, D. C., Sadler, T. D., \& Zeidler, D. L. (2017). Controversial Issues In The Science Classroom. Phi Delta Kappan, 99(4), 45-49.

Ozden, M. (2017). Prospective Elementary School Teachers' Views About Socioscientific Issues: A Concurrent Parallel Design Study. International 
Electronic Journal of Elementary Education, 7(3), 333-354.

Patricia, A. (2020). College Students' Use and Acceptance of Emergency Online Learning Due to COVID19. International Journal of Educational Research Open.

Peel, A., Zangori, L., Friedrichsen, P., Hayes, E., \& Sadler, T. (2019). Students' Model-Based Explanations About Natural Selection And Antibiotic Resistance Through SocioScientific Issues-Based Learning. International Journal of Science Education, 41(4), 510-532.

Pitpiorntapin, S., \& Topcu, M. S. (2016). Teaching Based On Socioscientific Issues In Science Classrooms: A Review Study. KKU International Journal of Humanities and Social Sciences, 6(1), 119-136.

Pope, T., Dawson, V., \& Koul, R. (2017). Effect Of Religious Belief On Informal Reasoning About Biotechnology Issues. Teaching Science, 63(2), 27.

Pratiwi, I. D., \& Laksmiwati, H. (2016). Kepercayaan Diri dan Kemandirian Belajar pada Siswa SMA Negeri "X". Jurnal Psikologi Teori dan Terapan, 7(1), 43-49.

Pratiwi, Y. N., Rahayu, S., \& Fajaroh, F. (2016). Socioscientific Issues (Ssi) In Reaction Rates Topic And Its Effect On The Critical Thinking Skills Of High School Students. Jurnal Pendidikan IPA Indonesia, 5(2), 164-170.
Pratono, A., Sumarti, S. S., \& Wijayati, N. (2018). Contribution Of Assisted Inquiry Model Of E-Module To Students Science Process Skill. Journal of Innovative Science Education, 7(1), 62-68.

Pursitasari, I. D., Suhardi, E., \& Putikah, T. (2019). Fun Science Teaching Materials on the Energy Transformation to Promote Students' Scientific Literacy. Jurnal Penelitian dan Pembelajaran IPA, 5(2), 155-168.

Purwati, R. (2019). Problem-Based Learning Modules with SocioScientific Issues Topics to Closing the Gap in Argumentation Skills. Turkish Online Journal of Educational TechnologyTOJET, 18(4), 35-45.

Qian, M., \& Clark, K. R. (2016). Gamebased Learning and 21st Century Skills: A Review Of Recent Research. Computers in Human Behavior, 63, 50-58.

Rahi, S. (2017). Research Design And Methods: A Systematic Review Of Research Paradigms, Sampling Issues And Instruments Development. International Journal of Economics \& Management Sciences, 6(2), 1-5.

Rahman, D. F. (2018). Analisis Argumentasi dalam Isu Sosiosaintifik Siswa SMP. Thabiea: Journal Of Natural Science Teaching, 1(1), 9-13.

Rigianti, H. A. (2020). Kendala Pembelajaran Daring Guru Sekolah Dasar di Banjarnegara. Elementary 
School: Jurnal Pendidikan dan Pembelajaran ke-SD-an, 7(2). 297302.

Rubini, B., Ardianto, D., Setyaningsih, S., \& Sariningrum, A. (2019, June). Using Socio-Scientific Issues In Problem Based Learning To Enhance Science Literacy. In Journal of Physics: Conference Series, 1233(1).

Rudibyani, R. B., Sunyono, S., \& Pandela, Y. S. (2019). Pengaruh Isu Sosiosaintifik dalam Meningkatkan Kemampuan Berpikir Kritis pada Materi Larutan Elektrolit dan Non Elektrolit. Jurnal Pendidikan dan Pembelajaran Kimia, 8(2), 295307.

Saad, M. I. M., Baharom, S., Eshah, S., \& Mokshien, M. A. B. S. (2017). The Study of Used Socio-Scientific issues (SSI) in Biology. International Journal of Academic Research in Business and Social Sciences, 7(3), 2222-6990.

Sadler, T. D., Foulk, J. A., \& Friedrichsen, P. J. (2017). Evolution of a Model For Socio-Scientific Issue Teaching And Learning. International Journal of Education in Mathematics, Science and Technology, 5(2), 75-87.

Sadler, T. D., Romine, W. L., \& Topçu, M. S. (2016). Learning Science Content Through Socio-Scientific Issues-Based Instruction: A MultiLevel Assessment Study. International Journal of Science Education, 38(10), 16221635.
Santika, A. R., Purwianingsih, W., \& Nuraeni, E. (2018). Analysis of Students Critical Thinking Skills In Socio-Scientific Issues Of Biodiversity Subject. In Journal of Physics:

Conference

Series 1013(1).

Setambah, M. A. B. (2018). Measurement Model Of Reasoning Skills Among Science Students Based On Socio Scientific Issues (SSI). IRJE (Indonesian Research Journal in Education), 74-85.

Siddiq, F., Scherer, R., \& Tondeur, J. (2016). Teachers' Emphasis On Developing Students' Digital Information And Communication Skills (TEDDICS): A new Construct In 21st Century Education. Computers \& Education, 92, 1-14.

Sismawarni, W. U. D., Usman, U., Hamid, N., \& Kusumaningtyas, P. (2020). Pengaruh Penggunaan Isu Sosiosaintifik dalam Model Pembelajaran Berbasis Masalah Terhadap Keterampilan Berpikir Tingkat Tinggi Siswa. Jambura Journal of Educational Chemistry, 2(1), 10-17.

Sofiatin, S., Azmi, N., \& Roviati, E. (2016). Penerapan Bahan Ajar Biologi Berbasis Kontekstual Untuk Meningkatkan Keterampilan Berpikir Kritis Siswa Pada Materi Perubahan Lingkungan Dan Daur Ulang Limbah (studi eksperimen kelas $\mathrm{X}$ MIPA di SMAN 1 Plumbon). Scientiae Educatia: Jurnal Pendidikan Sains, 5(1), 1524. 
Spies, T. G., \& Xu, Y. (2018). Scaffolded Academic Conversations: Access to 21st-Century Collaboration and Communication Skills. Intervention in School and Clinic, 54(1), 22-30.

Sundayana, R. (2016). Kaitan antara Gaya Belajar, Kemandirian Belajar, dan Kemampuan Pemecahan Masalah Siswa SMP dalam Pelajaran Matematika. Mosharafa: Jurnal Pendidikan Matematika, 5(2), 7584.

Suratno, S., Narulita, E., \& Luthfia, S. (2018). Pengembangan Buku Siswa Berbasis Kontekstual Bermuatan Nilai-Nilai Agama Islam Pada Materi Bioteknologi Kelas XII SMA/MA. Jurnal Edukasi, 5(1), 45-48.

Susanti, N., \& Djukri, D. (2018). Pengembangan Modul Biologi Berbasis Pondok Pesantren Untuk Menanamkan Sikap Spiritual Dan Kemandirian Siswa. Jurnal Inovasi Pendidikan IPA, 4(1), 64-74.

Suwono, H., Rizkita, L., \& Susilo, H. (2017). Peningkatan Literasi Saintifik Siswa SMA melalui Pembelajaran Biologi Berbasis Masalah Sosiosains. Jurnal Ilmu Pendidikan, 21(2), 136-144.

Tidemand, S., \& Nielsen, J. A. (2017). The Role Of Socioscientific Issues In Biology Teaching: From The Perspective Of Teachers. International Journal of Science Education, 39(1), 44-61.

Ulfa, I. S. K., Trapsilasiwi, D., \& Yudianto, E. (2018). Profil Berpikir Kritis Siswa dalam Menyelesaikan
Soal Fungsi Komposisi Melalui Model Pembelajaran Kolaboratif. Jurnal Didaktik Matematika, 5(1), 40-53.

Usher, E., Golding, J. M., Han, J., Griffiths, C. S., McGavran, M. B., Brown, C. S., \& Sheehan, E. A. (2020). Psychology Students' Motivation and Learning in Response to the Shift to Remote Instruction During COVID-19. Journal Preprint, 1-57.

Van Laar, E., Van Deursen, A. J., Van Dijk, J. A., \& De Haan, J. (2017). The relation Between 21st-Century Skills And Digital Skills: A Systematic Literature Review. Computers in human behavior, 72, 577-588.

Wan, Y., \& Bi, H. (2020). What Major "Socio-Scientific Topics" Should The Science Curriculum Focused On? A Delphi Study Of The Expert Community In China. International Journal of Science and Mathematics Education, 18(1), 6177.

Whorton, R., Casillas, A., Oswald, F. L., \& Shaw, A. (2017). Critical Skills for the 21st Century Workforce. Building Better Students: Preparation for the Workforce, 47-72.

Widiyawati, Y. (2020, April). Global Warming \& Climate Change: Integration Of Socio-Scientific Issues To Enhance Scientific Literacy. In Journal of Physics: Conference Series, 1511(1).

Yacoubian, H. A., \& Khishfe, R. (2018). Argumentation, Critical Thinking, 
Nature Of Science And

Socioscientific Issues: A Dialogue Between Two

Researchers. International Journal of Science Education, 40(7), 796807.

Yulastri, A., \& Hidayat, H. (2017). Developing an Entrepreneurship Module by Using Product-Based Learning Approach in Vocational Education. International Journal of Environmental and Science Education, 12(5), 1097-1109.

Yusro, A. C., \& Sasono, M. (2016). Penggunaan Modul Ilustratif Berbasis Inkuiri Terbimbing Pokok Bahasan Kinematika Gerak Lurus Untuk Meningkatkan Hasil Belajar Dan Kemandirian Siswa Kelas VII SMPN 14 Madiun. Jurnal Pendidikan Fisika Dan Keilmuan (JPFK), 2(1), 29-35.

Zamakhsyari, \& Rahayu, S. (2020). Fostering Ill-Structured ProblemSolving Skills Of Chemistry Students Using Socioscientific Issues As Learning Contexts. In AIP Conference Proceedings, 2215(1).

Zeidler, D. L., Herman, B. C., \& Sadler, T. D. (2019). New Directions In Socioscientific Issues Research. Disciplinary And Interdisciplinary Science Education Research, 1(1), 1-9.

Zulkarnaen, R. H., Setiawan, W., Rusdiana, D., \& Muslim, M. (2019). Smart City Design In Learning Science To Grow 21st Century Skills Of Elementary School Student. In Journal of Physics: Conference Series, 1157, (2). 